\title{
LAENSÕNADE TÄHENDUSSUHETEST
}

\section{Vilja Oja, Iris Metsmägi}

\begin{abstract}
Ülevaade. Eesti keelde laenatud sõna ei kopeeri alati laenuallika tähendust või tähendusi, vaid omandab sageli sellest kitsama või laiema või hoopis uue tähenduse. Selle põhjuseks on kultuuride erinevus, paikkondlikud etnograafilised iseärasused, eri taime- ja loomaliikide levik, tabu jm. Rahvaetümoloogia mõjul võib sõna tähendus muutuda nii, et seos laenuallikaga puudub. Tähendusmuutus on sageli toimunud hiljem, mitte laenamise käigus, ning tingitud olude või esemete muutumisest. Mõnel juhul on sama sõna laenatud korduvalt, eri aegadel erinevas tähenduses. Sõnade ja nende tähenduste levik murretes aitab määrata laenude liikumise teid ja ühtlasi avastada murdealati eri suunast tulnud laene. Teiselt poolt aitab eesti sõna päritolu täpsustada võrdlus sarnase keelendi kasutusega sugulaskeelte ja kontaktkeelte murretes. Sõnade tähendussuhteid tuleb kindlasti arvestada nii keeleõppes ja tõlketöös kui ka sõnade päritolu määratlemisel.*
\end{abstract}

Võtmesõnad: etümoloogia, keelekontaktid, murdesõnavara, sõnalevik, tähendusmuutus, eesti keel, läänemeresoome keeled

\section{Sissejuhatus}

Sõnade päritolu on sageli püütud tõestada üksnes või eelkõige keeleajalooliste häälikumuutuste varal, ehkki termin "etümoloogia” lähtub mõistest 'tähendus', kreeka etymon. Ka tõlkimisel on oht samastada laensõna häälikkujult sarnase võõrkeelse vastega, süvenemata tähendusnüanssidesse. Käesolev artikkel käsitleb laenude semantilist külge. Tähelepanu keskmes on eesti sõnade tähenduserinevused võrreldes doonorkeeltega, kuid selle kõrval näidatakse ka erinevusi murretes ja läänemeresoome keeleruumis. Uurimuses analüüsitakse muutuste liike ja põhjusi ning võimalikke laenude kulgemise teid. Järelduste tegemisel arvestatakse sõna ja selle tähenduste levikut murretes, lähisugukeeltes ja kontaktkeeltes. Näited on valitud põhiliselt uuemate laenude hulgast, mis on eesti keelde tulnud pärast 12. sajandit. Mõne nähtuse puhul kõrvutatakse uuemaid ja vanu laene. Sõnade 
päritolu osas on aluseks "Eesti etümoloogiasõnaraamat” (Metsmägi jt 2012), teistele allikatele viidatakse tekstis.

Tähenduserinevusi on laias laastus kolme liiki. Laensõna võib originaaliga osaliselt kattuda, märkides kas 1) kitsamat või 2) laiemat mõistet kui doonorkeeles, või 3) omandada uue tähenduse. Nimetagem olukorda, kus laensõna tähendus on kitsam kui laenuallikal, tähenduse kitsenemiseks, vastupidist situatsiooni tähenduse laienemiseks ning täielikku erinevust tähenduse teisenemiseks. Keeles kodunenud laensõna allub edasistele muutustele ning alati ei õnnestu välja selgitada, kas tähendusmuutus toimus laenamisel või hiljem.

\section{Tähenduse kitsenemine}

Laensõna tähendus saab kitseneda üldjuhul siis, kui originaalkeele sõna on kas mitmetähenduslik või märgib suhteliselt laia mõistet. Paljudel juhtudel on doonorkeeles mitmetähenduslik sõna laenatud eesti keelde tähistamaks vaid ühte või osa originaali tähendustest. Näiteks eesti kleit < sks Kleid 'kleit, rõivas, rüü'; nööp < asks knōp 'nööp; nupp; pung; sõlm'; pood 'kauplus' < asks bode 'väike käsitööliste jt "tähtsusetute” inimeste maja; barakk, telk; käsitööliste müügi- ja tööruum'; plaaster 'nahale asetatav raviotstarbega kate (nt haavaplaaster, sinepiplaaster)' < asks plāster 'plaaster; sillutis, tänavakate'. Erijuhtudel tuntakse laensõna üksnes ülekantud tähenduses, nt eesti kelm < asks schelm 'korjus, raibe', piltlikult 'kelm, lurjus'.

Ainsas tähenduses laenatud sõna võib kinnistuda veelgi kitsamat mõistet tähistava terminina, nt eesti moos < asks mōs 'kapsas, köögivili; puderjas toit'. Hoopis laiema tähendusega on samast algtüvest lähtuv soome kõnekeelne muusi 'pudi; puder; püree; moos', mis on laenatud ilmselt rootsi keelest, vrd rts mos id. ning verb musa 'pudiks või pudruks teha' (> soome muusata id.) (PS 2: 255). Soome etümoloogilistes sõnaraamatutes see sõna puudub. Ahjulõorri keeratavat (kaanetaolist) siibrit märgib eesti keeles vene laen kriska < vn крышка 'kate, kaas; luuk; klapp', eesti murretes ka krïska, krõ(õ)ska jms (vt EMS III: 849, Must 2000: 141). Põhjaeesti keeles ja osalt Mulgi murdes on lihapoodi nimetatud karn, gen karni (ka karnits, kärn) < asks scharne 'lett, lettide kogum; ruum, kus letid paiknevad' (EMS II: 758, 760).

Kitsamas eritähenduses on eesti keelde laenatud ka selliseid sõnu, mis doonorkeeles väljendavad laia üldmõistet, nt kee 'lülidest koosnev kaelaehe' < asks kede, kedene 'kett'; leer 'noorte õpetamine ning ettevalmistamine kogudusse vastuvõtmiseks' < asks lere ‘õpetus, õppimine'; paak 'masina, seadmestiku vm vedelikumahuti' < asks bak 'anum, küna'.

Laensõna tähendus võib kitseneda korduvate keelekontaktide tagajärjel. Näiteks kang 'kitsas käik või läbipääs; võlvialune läbikäigukoht' on laenatud kas alam- või ülemsaksa keelest, < asks gank 'käimine; rongkäik; käik, tee; komme, harjumus' või < sks Gang 'kõnnak; (jalutus)käik, teekond; koridor, käik; kang, kangialune; kulg'. Juhul, kui algselt laenati alamsaksa sõna tähenduses 'käik, tee', muutus see hiljem saksa mõjul konkreetsemaks. 20. saj eesti keeles oli kang üldtuntud võlvialuse läbikäigu nimetusena (kangi all, kangialune), ent varasem tähendus säilis näiteks Tallinna tänavanimes Saiakang. 
Üks ja sama laentüvi ei väljenda alati sama tähendust üksiksõnana ja liitsõna osana. Sel juhul on liitsõna tavaliselt eraldi laenatud. Näiteks saksa laen kreis (< sks Kreis) märgib eesti keeles varasemat haldusüksust Saksa- ja Venemaal ning Eesti maakonda 18.-19. saj. Saksa keeles on selle sõna põhitähendus 'ring, sõõr' ning sellest lähtuvad muud tähendused, nagu 'ringkond, teatud seltskond, grupp; sfäär, tegevusala; haldusüksus, piirkond'. Sama tüvi esineb teises tähenduses liitsõnas kreissaag 'ketassaag', mis ei ole moodustatud eesti keele baasil, vaid on omaette laen < sks Kreissäge id. Verb leierdama 'tüütuseni kordama' < sks leiern 'väntorelit mängima; kõnek 'ühtesama jorutama; monotoonselt lugema' ei seostu eesti keeles otseselt leierkastiga. Liitsõna leierkast 'väntorel' < sks Leierkasten id. on laenatud eraldi, kusjuures liitsõna järelosis kast on võtnud varasema, alamsaksa laenu kuju (vt ptk 4).

\section{Tähenduse laienemine}

Laienenud tähendust kohtame mitmes laenatud loomanimetuses, kus noorlooma või ühest soost isendi nimetusest on saanud liigi üldnimetus, nt eesti kits 'veislaste hulka kuuluv keskmise suurusega imetaja, kodukits, metskits' < sks Kitze 'kitsetall, metsvõi mägikitse tall'. Eesti kass on laenatud vene keelest < vn кошка, murdekeeles коша, кошара, кошура 'emakass'. Koduloomade nimetused on üldse omavahel mitmel viisil segunenud. Niisugused tähenduse varieerumised tulevad hästi esile murdekeeles, eriti kui vaadelda läänemeresoome ainest tervikuna (vt ptk 5).

Algselt ühte mõistet tähistav laensõna võib originaaltähenduse kõrval omandada täiesti uusi lisatähendusi. Laensõnad, mida kirjakeeles kasutatakse originaalist laiemas tähenduses, võivad murdeti olla doonorkeelega tähenduselt identsed. Näiteks eesti põhjarannikul, Risti, Jõelähtme ja Kuusalu murrakutes nimetatakse

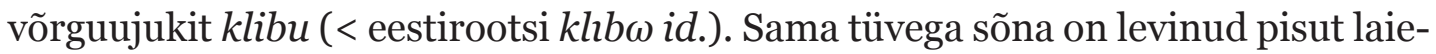
malt põhjaeesti murretes tähenduses 'lapikud kivikesed; miski väike, väärtusetu, tühine'. Eesti kirjakeeles tuntakse seda sõna just viimases tähenduses ning selle baasil on nii murde- kui kirjakeeles moodustatud tuletised klibune, klibuline, klibustik (EKSS 2: 326, EMS III: 320).

\section{Tähenduse teisenemine}

Ka siis, kui laensõna ja originaali ükski tähendus ei kattu, on tähenduse muutus toimunud mingi seose alusel. Eesti vaste väljendab enamasti laenuallikale lähedast mõistet. Näiteks osmikut ja väikelooma putkat märkiv kuut (murdekeeles ka kut't, kuudik) < läti kūts 'loomalaut'; küüt 'vedu' < vana-rts skiut 'veohobune; mära'; eesti rahvustoiduna tuntud kama 'kaun- ja teraviljajahu segu ning sellest valmistatud toit' < vn murdesõna комы (mitmus) 'saiakesed, leivad, pannkoogid'. Lööbega nakkushaiguse nimetus leetrid on levinud peamiselt põhjaeesti murretes (ka leedrid, leeted jt häälikuvariandid) ning mõni keelejuht on selle tähenduseks öelnud 'tuulerõuged' (EMS V: 42-43). Etümoloogiasõnaraamatus on see esitatud alamsaksa laenuna (< asks bladder, bledder, bledere 'vill, rakk'). Eesti sõna mitmuslik vorm näitab, et haiguse nimetus väljendab sel juhul mõistet 'villikesed, lööve’ vms. 
Paljude laensõnade sisulist seost laenuallikaga ei ole tänapäeval enam lihtne tajuda, see ilmneb alles taustteabe ja selgituste varal. Näiteks laat on eesti keeles üldtuntud tähenduses 'suur ajutine turg' vms. Laen pärineb alamsaksa sõnast afflade 'patukustutus, indulgents' ja seostub eesti sõnaga sel teel, et kirikupühadel kuulutati pattude andeksandmist ja peeti ka laatasid. Vanemat eesti elu kujutavas kirjanduses esineb sõna vonn, gen vonni 'mõisnik, saks' < sks von (eessõna; aadlitiitel). Nimelt hakati Saksamaal 17. saj seest- ja alaltütleva käände tähendust märkiva eessõnaga von tähistama aadlipäritolu. Tarbetuid jäätmeid, puru, rämpsu märkiv prügi (< asks brugge 'sild, tänav', varem 'tamm') tuleneb sellest, et tammi põhja täitena kasutati muuhulgas prahti. Täidlast, tüsedavõitu inimest või looma iseloomustab omadussõna priske < asks vrisch 'noor, värske, rõõmus'. Vanemas eesti keeles kasutati seda sõna tähenduses 'elujõuline; värske', kõnekeeles ka 'suur, tõhus, rikkalik, tugev vms', murretes ka 'ilus', nt Põlva murrakus ega mïss haard priśkit, kestu hirmsat [neiut] taht (EMSUKA, Wiedemann 1973: 876). Samast tüvest on tulnud Leivu murraku priš'š 'värske' < läti prišs id. (< sks frisch) ja liivi Kuramaa murde priš id., mis võib olla laenatud otse saksa keelest või läti keele vahendusel (ALFE 3: 315-318, Suhonen 1973: 181-182).

Kõige kardinaalsemaid tähenduse muutusi tekitab rahvaetümoloogia, kus laensõna ühitatakse häälikuliselt lähedase, keeles juba varem esineva, hoopis teise päritolu ja tähendusega tüvega. Sel viisil võidakse sõna tõlgendada vale mõiste baasil. Näiteks punakas- või pruunikaskollast värvust märkiv eesti paat, gen paadi on läti laen (< läti pãtis, pãts 'kahvatu pruunikaskollane, kollane') ning eesti keelest omakorda on laenatud soome ja isuri murretes hobuse värvust kirjeldav paatti 'kollakas, helepruun' (Oja 2003: 101-102, Vaba 1997: 146-147). Eesti sõna on mõnikord ekslikult seostatud paekivi nimetusega, määratledes tähenduseks 'paekarva'. Rahvaetümoloogia tõttu võib keelend omandada ka varem tuntud sõna kuju koos tähendusega, nt orleani kollane 'oranž' > ordenikollane 'kuldkollane'. Rahakoti vananenud nimetusena tuntud tengelpung on baltisaksa laen ( $<$ baltisaksa Denkelbuch 'kirjatasku, taskuraamat, kirjutustahvel', sks denken 'mõtlema; arvama; kavatsema; kujutlema', Buch 'raamat'). Eesti keeles on sõna osiseid seostatud juba varem keeles esinenud laensõnadega teng 'raha' (< vene денъга 'raha') ja pung van 'rahakott' (< asks punge 'tasku, väike kott' või < rootsi pung 'rahakott, kukkur; tubakakott'). (Ariste 1942: 20, Viires 196ob: 158.) Niisuguseid tähendusmuutusi kohtab sageli eesti kohanimedes, eriti neis, mis on lähtunud võõrastest, kohalikust pruugist kadunud isikunimedest (vt nt Kallasmaa 2000: 134).

Laenude liigitus tähendusmuutuste alusel on tinglik. Mitmetähenduslikkust eristab üldisest tähendusest mõnikord vaid kategoriseerimise detailsus. Tänapäeva kirjakeeles teisenenud tähendusega sõna on võidud varem või murdekeeles kasutada laenuallikaga samas tähenduses. Laensõna võib originaalist erineda ka sel moel, et osa tähendusi puudub, aga samas on uusi juurde tulnud, nt kast (< asks kast(e), kass 'hoiukoht või -kamber, mahuti, kast; sõrmusekivi pesa; [talus] peenestatud õlgede hoiuruum; vangla; mõõtühik') tähistab eesti keeles mõisteid 'puust vm materjalist (täisnurkne) säilitus-, transportimis- vms vahend; joonistatud nelinurkne kujund'; murdekeeles 'rehealuse kõrval olev ruum, kuhu vili viidi enne ahtmist; sillaalune palkidest tugiehitis; pidemed adrahargi keskosa ümber' (EKSS 2: 138-139, EMS II: 811-812). Wiedemanni sõnaraamatu andmetel on seda sõna kasutatud ka tähenduses 'talupojavangla' (1973: 218). 


\section{Tähendusmuutuste põhjused}

Sõna laenatakse enamasti koos mingi uuendusega, mistõttu kultuuriuuendus ja laensõna tulevad tihti samast allikast. Laen tähistab sellisel juhul konkreetset uut objekti, nt kriska 'ahjulõõri siiber', paak 'vedelikumahuti', plaaster, kreissaag, leierkast, kuigi doonorsõna võib olla mitmetähenduslik või tunduvalt laiema tähendusega (vt ptk 2). Sakslaste kaudu tuntuks saanud söögiriist kahvel (murdekeeles ka kahver) omandas nimetuse alamsaksa keelest < asks gaffele 'puust või rauast hark millegi tõstmiseks'. Eesti keeles olid olemas suured tõsteriistad hang ja hark, niisiis laenati kahvel üksnes söögiriista nimena. Purjehargi ja mitmesuguste masinate või sõiduriistade kaheharulise osa nimetusena võib kahvel olla hilisem laen samast allikast või hoopis ülemsaksa või rootsi keelest. Merenduse ja kalastusega seotud sõnavara on hollandi (ja alamsaksa) keelest levinud paljudesse Euroopa keeltesse, sealhulgas rootsi ja saksa keelde, ning sageli ei ole võimalik täpselt kindlaks teha, missugusest keelest need sõnad on eesti keelde laenatud. Millegi hargikujulist osa märgib kahvel vms vaid põhjaeesti murretes, üldtuntud söögiriista nimetus on levinud kõigis murretes (EMS II: 535-536). Mitmed sõnad on laenatud tähistamaks konkreetseid ühiskonnaelu toiminguid ja uusi nähtusi või riigikorraldust puudutavate terminitena, nt kreis, leer (vt ptk 2).

Uus, laenuallikale lähedane, kuid sellest erinev tähendus, on mõnel juhul seotud tabuga. Tabu tõttu on näiteks jahiloomade ja kardetavate metsloomade nimetusi püütud vältida, asendades need teiste, sageli laenatud nimetustega. Nii on hundi algläänemeresoome-aegne nimetus susi (< *śunte < IE ḱunto-) põhjaeesti ja kohati soome murretes asendatud saksa laenuga: eesti ( $h$ )unt, soome huntti (< sks Hund 'koer'), osas soome murretes vanavene (või vene) laenuga hurtta, vrd vana-vn xъpmъ, vn xopm ‘jahikoer, hurt' (vt ALFE 3: 319-322, Plöger 1973: 56, SSA 1: 192, Zaitseva 2009: 240 jj).

Huvitavaid tähendusmuutusi on toimunud koduloomade nimetustes (vt ka ptk 3). Näiteks kitse märkivat soome sõna kili (murretes ka kila, kili, kile, kilu, kilo < rts killa, kille, kilu (van) 'kits' < skandinaavia) kasutatakse kohati üldnimetusena, kohati emaslooma või kitsetalle nimetusena (vt ALFE 3: 138-140, SMS 7: 197, 199, 202, 224-225, 241). Isuri keeles ja idavadja murdes on kili kodu- ja/või metskitse üldnimetus (Nirvi 1971: 164-165, VKS 2: 162). Eesti murretes esineb sõna kahel kujul: idamurdes ja Viru-Jaagupi murrakus kile, Setus lastekeelne kilõ '(isane või emane) kitsetall' ja saarte murdes (Karja, Emmaste, Pühalepa murrakutes) kilu 'kits; emane kitsetall' (EMS III: 128, 142). Üldnimetuse kokkulangevus emaslooma nimetusega on ilmselt tingitud sellest, et emaseid peeti rohkem. Väikeloomade nimetused levisid sageli hellitusnimedena. Paljud koduloomade nimetused on vanad balti laenud ega kuulu otseselt käesoleva teema raamesse, aga näitavad ilmekalt muutuste põhjusi. Väikelooma nimetusest on mõnel juhul kujunenud kohitsemata looma nimetus. Näiteks põhjaeesti ja kohati soome murretes tähistab baltlastelt laenatud lambatalle nimetus isaslooma: eesti jäär, soome jäärä < balti, vrd preisi eristian 'tall', leedu èras, läti jērs 'lambatall'. Selle kõrval on läänemeresoomlased laenanud ka isaslooma nimetuse: lõunaeesti ja soome oinas, vepsa oinaz, liivi (Salatsi) oin, oen 'oinas', karjala oinaš 'oinas, utt', põhjaeesti oinas 'kohioinas' < balti, vrd preisi awins 'oinas', leedu avinas, läti auns, murdeti avęns, avins jm (LVDA: 121-122, ME 2: 114). Omapärane tähendusmuutus on toimunud sõna härg 
laenamisel. Traditsiooniliselt on seda peetud laenuks balti keelte hobusenimetusest, vrd leedu žirgas, läti zirgs 'hobune', preisi sirgis 'täkk'. Kõigis läänemeresoome keeltes märgib see veist, põhiliselt isast või kohilooma: eesti härg ja liivi äärga 'härg', vadja ärtšä ja vepsa härg 'härg; pull, sõnn', soome härkä 'veis: pull, sõnn; härg', karjala härkä 'pull, sõnn' (häälikkujud ja levik vt ALFE 3: 121-124). Karjala ja vepsa murretes on nõnda nimetatud ka isast põtra või põhjapõtra (KKS 1: 392, SVJ: 141). Balti hõimudelt on seega laenatud (põllutöödel kasutatava) veolooma nimetus, mille tähendus muutus vastavalt kohalikele oludele.

Looduslikud erinevused, eri taime- ja loomaliikide levik, põllumajanduslikud tavad jms on põhjustanud ka hilisemate laensõnade tähendusmuutusi, nii et sarnased laensõnad tähistavad läänemeresoome keeltes erinevaid taimi või loomi. Näiteks samast allikast laenatud kaal-tüveline sõna märgib läänemeresoome keeltes kahte erinevat köögivilja: soome ja isuri kaali ning lõunakarjala koali 'kapsas, Brassica oleracea', vrd rts, norra, taani kål, islandi kál id. (ALE 1, 7: kaart 76), aga eesti kaal, kaalikas 'Brassica napus rapifera' < vana-rts kaal, kal 'kapsas'. Eesti keelega samas tähenduses esineb see sõna balti keeltes: läti kālis 'kaalikas' (< rts või asks), mis on levinud Vidzeme ja Zemgale murretes ning Kurzeme kirdeosas, ning leedu põhjaosas kolis (? < läti) (BVA 2009: 111, 154-155, LVDA: 116, kaart 47). Mõlemad juurviljad on aretatud looduslikest Vahemere-äärse kapsasrohu (Brassica) liikidest (ENE 4: 181, 310). Taimede kaugem originaalnimetus vanakreeka kaulós lähtub mõistest 'vars' (SAOB s.v. kål; Wharton 1974: 66). Sellised tähenduserinevused võivad viidata erinevale laenamise ajale.

Laensõna allub hiljem tavaliselt eesti keele harilikele tuletusreeglitele, mille tulemusena tekivad sama tüvega uued sõnad. Näiteks kratt 'pisuhänd, tulihänd ehk puuk' (< eestirootsi skrat 'kummitus, kurat') esineb põhjaeesti läänepoolsemates murretes (Jõelähtme, Kuusalu, Hiiu murrakud, läänemurre, keskmurde põhjaosa), sellest tuletatud verb krattima '(korduvalt vähehaaval) varastama' on registreeritud vaid Hiiumaalt Emmaste ja Reigi murrakutest (EMS III: 817-818). Kirjakeeles on nii noomen kui verb saanud laialt tuntuks, kusjuures nimisõna kasutatakse ka piltlikus tähenduses vallatu lapse kohta, nt poisikratt (EKSS 4: 345).

Sageli on sõna tähendus muutunud hiljem, mitte laenamise käigus. Näiteks Viljandimaa lõunaosa elanike nimetuse mulk (< läti muļķis, muļ̧̧̧e 'narr, lollpea') kohta on arvatud, et algselt laenati see sõna Mulgi murdesse läti keelega sarnases tähenduses. Teistelt murdealadelt naabrite hulgas sai see mulkide hüüdnimeks, millest hiljem kujunes hõimunimetus (Vasmer 1920: 345 ja 1922: 13). Läti keelega sarnases tähenduses kasutatakse sõna muĺk Saaremaal Jämaja murrakus ja mu'ĺki liivi keeles, mis on eraldi laenud samast läti sõnast (Kettunen 1938: 233, Suhonen 1973: 160, Vaba 1997: 136). Saksa Krebs 'vähktõbi, kartsinoom (pahaloomuline kasvaja); vähk (veeloom)' on eesti keelde laenatud esimeses tähenduses kreeps, gen kreepsu (van) 'vähktõbi (pahaloomuline kasvaja)', mis kõnekeeles on hiljem teisenenud, märkimaks mõistet 'rabandus; vapustus'.

Sõna hilisemad tähendusmuutused on sageli tingitud olude või esemete muutumisest. Kui mingi tööriist või muu konkreetse otstarbega ese asendatakse täiuslikuma, sama või eelmisele lähedast funktsiooni täitva esemega, on endise nimetuse kasutamine küllalt tavaline. Näiteks hoorattaga ketrusriista märkiv vokk < asks wocke, sks Wocke 'kedervars; koonal; koonlalaud' võis olla laenatud esmalt kedervarre nimetusena ning sai uue tähenduse 17. saj, kui vokk Eestis laiemalt tuntuks sai (Ariste 1980a: 371-372, Viires 1960: 184). 


\section{Laensõnade ja nende tähenduste levik abiks etümologiseerimisel}

Laensõnade tähendusmuutuste tuvastamine ja põhjendamine on sageli keerukas ja aeganõudev, sest see eeldab ulatusliku keeleainese (sealhulgas murdeainese) analüüsimist semantilisest aspektist ja taustteabe kogumist. Teiselt poolt pakub sõnade päritolu uurimine mõnigi kord ootamatuid avastusi ja rõõmsat äratundmist. Näiteks siis, kui saadakse kinnitust kaheldavale etümoloogiale või leitakse varem omatüveks (sageli deskriptiivseks) peetud sõnale vasteid sugulas- või kontaktkeeltest. Etümoloogiat aitab täpsustada võrdlus sarnase sõnaga kontaktkeelte murretes, pidades seejuures silmas nii levikut kui ka tähenduslikku külge. Näiteks Võru murdesõna villan villań 'naiste sõba; muistne villane seelik' tundub olevat tavaline eestikeelne ne-sufiksiga tuletis sõnast vill, tegelikult on aga läti laen, vrd läti villane, vilnaine 'villane suurrätt, sõba' (Vaba 1997: 242). Sageli on laensõna laialt levinud just algsest erinevas, muutunud tähenduses, kuid säilitanud algse tähenduse murdekeeles. Ala, kus laensõna esineb doonorkeelsega samas tähenduses, võib olla laenu lähtekoht, nt eesti klibu on tõenäoliselt hakanud levima põhjaranniku läänepoolsetest murretest (vt ptk 3).

Mõnigi kord on lisateave kujundanud sõna etümoloogia suhtes varasemast erineva seisukoha. Endisaegset kodukootud villast triibulist või ruudulist seelikut nimetati Pärnumaa ja Läänemaa lõunaosa murrakutes kört, gen kördi (Saareste 1938: kaart 9). A. Saareste on omal ajal pidanud seda rootsi laenuks < rts skört 'seeliku eesmine osa', vrd ka skandinaavia skyrta 'naiste põll' (1924: 165-166). Eesti murdesõnavara kogu põhjal esineb sõna samas tähenduses ka Muhu, Suure-Jaani ja Viljandi murrakus ning Mulgi murdes (EMS IV: 618). Eesti etümoloogiasõnaraamatu andmeil on eesti sõna laenatud alamsaksa keelest < asks schorte, mis tundub usutav, sest sõna levik ei kattu tüüpilise rootsi laenude alaga. Eesti keelest laenatud liivi (Salatsi) murdesõna kört kürt 'naiste seelik' on seostatud sama alamsaksa sõnaga (Kettunen 1938: 179, SSA 1: 485, SLW: 103). Soome murretes märgib körtti kohati seelikut, jämedakoelist värvilist alusseelikut või põlle, kohati jaki vöökohast allapoole ulatuvat osa ning see on tunnistatud rootsi laenuks < rts skört, van skörte (SSA 1: 485).

Viimastel aastakümnetel avaldatud keeleatlased (ALFE, ALE, LVDA jt) pakuvad võimalusi eesti murdesõnade ja nende tähenduste leviku võrdlemiseks läänemeresoome keeleruumis ja teiste Euroopas kõneldavate keelte murdematerjaliga. Laensõnade ja nende tähenduste levik on osutanud murdealati või keeliti eri suunast tulnud laenudele. Sageli on ühise indoeuroopa tüvega sõnad läänemeresoome murretesse laenatud erinevate keelte kaudu, nt germaani algupäraga klee-/klöötüvelised ristikheina nimetused: eesti klee, vrd sks Klee; soome (k)lööveri, vrd rts klöver; muud variandid, nagu (k)leever, kliever jt, vrd vn клевер (ALFE 2: 57-62, Oja 2011: 131, 135). Rootsi ja saksa laenud tähistavad tõenäoliselt kultuurristikut, vene laenud looduslikku taime.

Indoeuroopa keeltes mitmes tähenduses kasutatav sõna võib läänemeresoome murretesse olla laenatud erinevail aegadel eri tähenduses. Jättes kõrvale kirumissõna funktsiooni, märgib noomen pakana läänemeresoome keeltes peamiselt kaht teineteisest erinevat mõistet: eesti, vadja, liivi ja kohati soome ja karjala murretes 'mittekristlane' ning karjala, vepsa, vadja, liivi, isuri ja mõnedes soome murretes 
'halb, kuri (inimene või loom); räpane, kõlbmatu, väärtusetu (asi, nähtus vms)' (vt ALFE 2: 253-257). Viimases tähenduses loetakse sõna üldiselt vanavene laenuks, mille kaugem allikas on ladina paganus 'külaelanik, talupoeg', adj 'maaelule omane', kusjuures idapoolsetes läänemeresoome keeltes on oletatud hilisemaid vene mõjutusi, vrd vn погань 'jälkus, ilgus, rämps', поганый 'mittesöödav; vastik; vilets, rämps' (SSA 2: 294). Hiljem on vene keelest eesti Setu murrakusse laenatud o-lised variandid: noomen pogan, pogań 'kõlbmatu, vastik, räpane, paha jms', sama tüvega adverb poganahe 'räpaselt' ja verb pogandat 'solkima, mustaks tegema' (ALFE 2: 256, EMSUKA). Sõnad tähenduses 'mittekristlane’ pärinevad hilisemast ladina keelest ning on laenatud tõenäoliselt eesti ja liivi keelde saksa ning soome keelde rootsi keele vahendusel. Siit omakorda on need levinud vadja, isuri ja karjala (peamiselt Aunuse) murretesse (ALFE 2: 256, Viitso 2006: 894-897).

Samatüveliste sõnade kasutus erinevail Eesti murdealadel erinevas tähenduses viitab sellele, et siingi võivad sõnad olla saadud eri teid pidi, nt kitse nimetused kile, kilõ Ida-Eestis ja kilu läänesaartel (vt ptk 3); muĺk Jämaja murrakus ja mujal (vt ptk 5). Tänapäeva eesti keeles meeste pintsakut märkivat sõna kuub on kasutatud vanemas keeles ja murretes mitme riietuseseme nimetusena. Sõna on levinud peamiselt põhjaeesti murretes, lõunaeesti murretest (Mulgi, Tartu) on harvad uuemad kirjapanekud (EMS IV: 138-139). Kõige laiemalt tunti seda tähenduses 'pikk villane meeste või naiste üleriie' (kaart 1: a), millest ilmselt tulenebki uus, praegune sõnakasutus. Vana tähendus on tänapäeval tuntud Mulgi meeste rahvarõiva pikk-kuue nimetuses (selle varasem nimetus oli vammus) ning märgib pikka üleriiet liitsõnades nagu mungakuub, preestrikuub, vihmakuub jt. Põhjarannikul ja kohati Läänemaal oli kuub laste (nii tüdrukute kui ka väikeste poiste) särgitaoline riietusese või kleit (kaart 1: b; vt ka Saareste 1924: 171). Saaremaal ja Hiiumaal oli kuub naiste seeliku põhinimetus (kaart 1: c). Üksikteateid on seeliku või seda märkivate murdesõnade paralleelnimetusena ka teistest põhjaeesti murretest, osalt tähenduses 'alusseelik' (Saareste 1924: 165, 167 ja 1938: kaart 9). Mandril on kuub seeliku nimetusena uuem kui saartel. Peale selle on Hargla murrakust kirja pandud kuup : kuuba 'kuub', liitsõna kuubarõõvass ja deminutiiv kuubakõnõ (EMS IV: 139, 166). Sõna kuub peetakse alamsaksa laenuks, ehkki sobivat doonorsõna pole sealt leitud. Tõenäoline keskülemsaksa vaste schūbe, schoube 'lihtne pikk üleriie' (sks Schaube 'naiste seelik või mantel') arvatakse tulenevat itaalia sõnast giubba, mis pärineb araabiakeelsest pikkade varrukatega üleriide nimetusest (Vasmer 4: 482). Levikut arvestades võiks seelikut tähistava sõna puhul kõne alla tulla ka teiste germaani keelte mõju.

Ühest algallikast pärineva, kuid eesti keeles mitut üsna erinevat mõistet märkiva sõna puhul võib tegemist olla eriaegsete laenudega. Nimisõnal kudrus on eesti kirjakeeles ja murretes kaks tähendust. Põhjaeesti murretes on sõna laialt levinud tähenduses 'väike klaas- või kivihelmes' (Hiiumaal ja Kirbla murrakus kudru) ja hajalevikuga tähenduses 'lõnga- või villakruss, juuksekihar' (vt kaart 2). Vastseliina ja Setu murrakuis tuntakse variante kudrä, kudra, mis tähendavad 'juukselokk, kihar', adj 'kähar, lokiline' ning verbi kudrätämä 'lokkima, kähardama'. Teise tähenduse alusel on moodustatud määrsõnad kudrus, kudris 'krässus, krussis' ja rida omadussõnu, esimese baasil liitsõnad kudruskael murdekeeles 'kirju kaelaga lind', rahvaluules 'neiu' ja kudrustükk 'pärlitikandiga seelikualane' (EKSS 2: 524, EMS III: 940-941, Wiedemann 1973: 398). 
a.

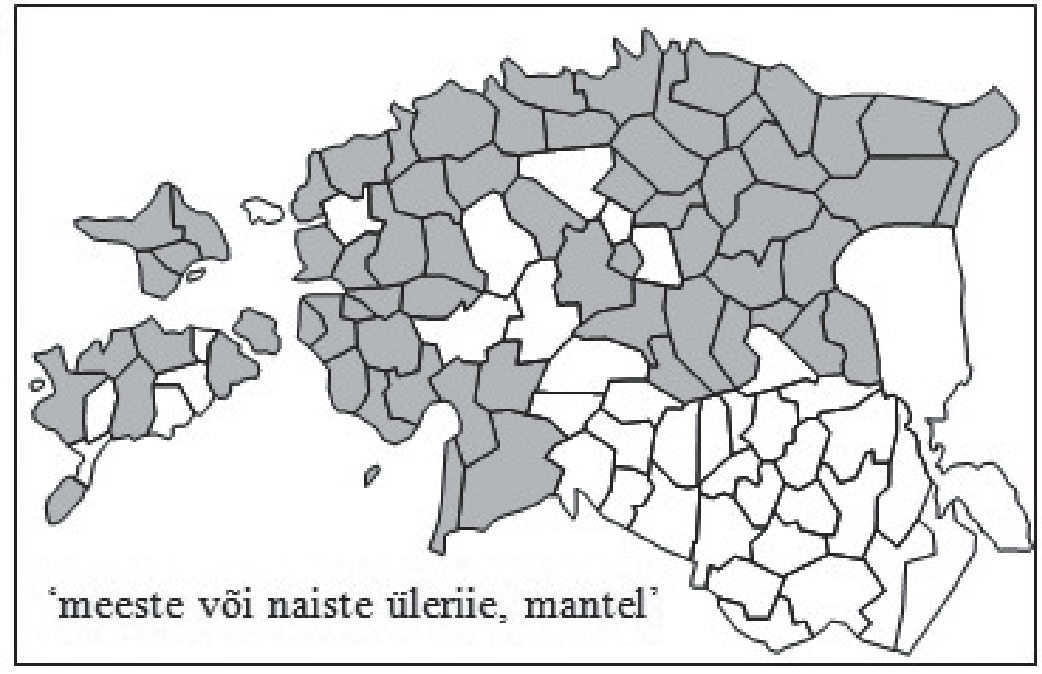

b.

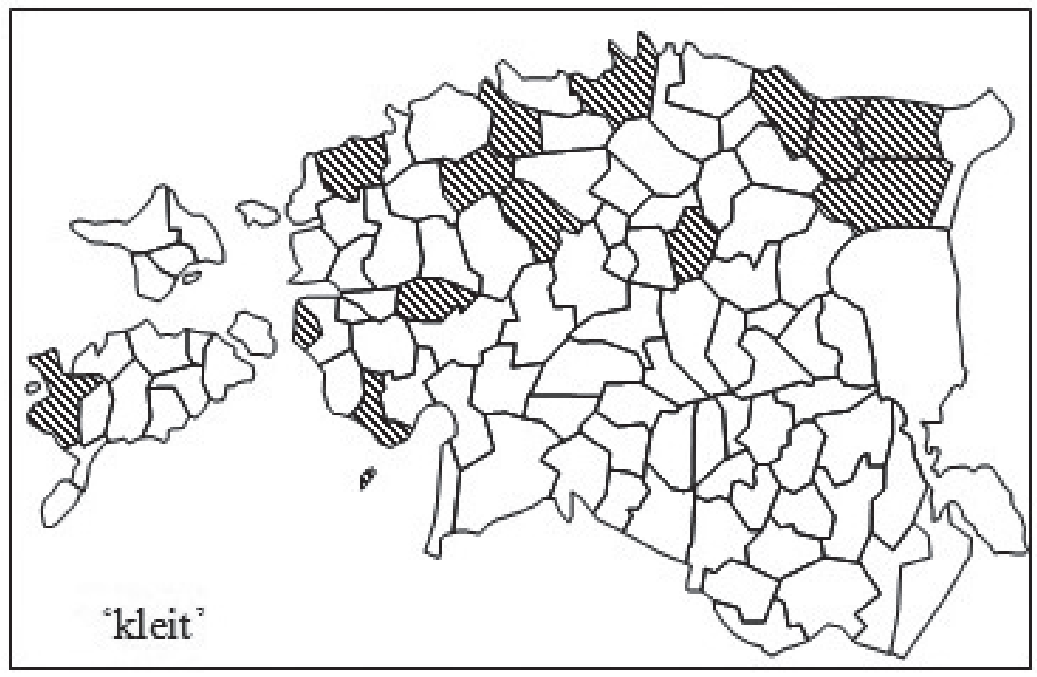

c.

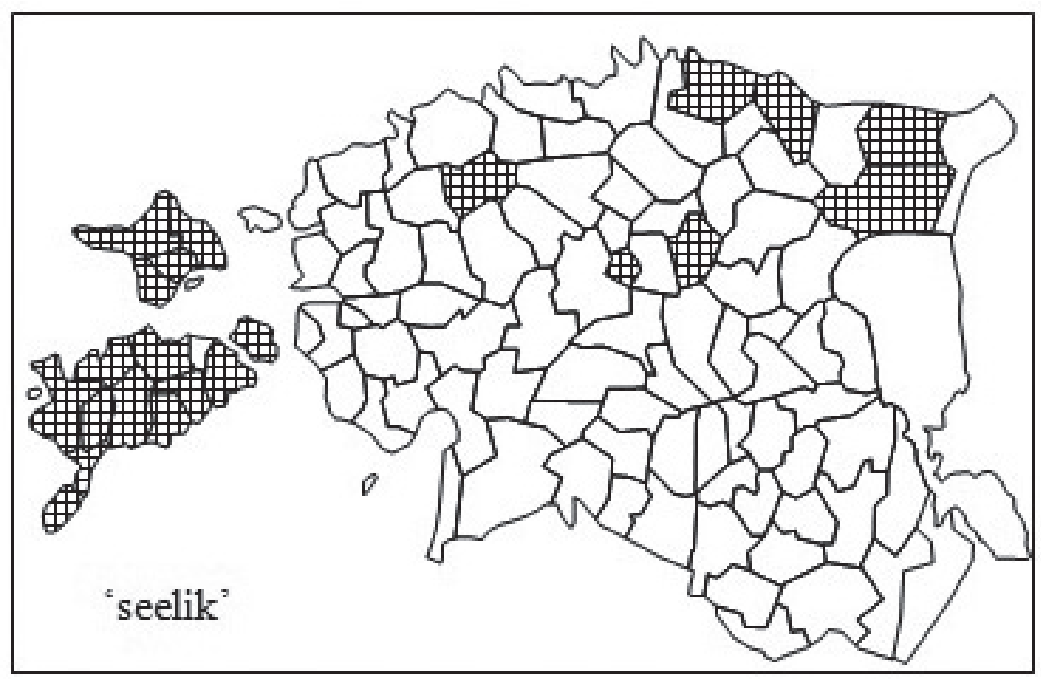

Kaart 1. kuub, tähendused eesti murretes 
Võru murdesõna on suhteliselt hiline vene laen < vn кудерь, кудря 'lokk, juuksekihar', mitmus кудри. Põhjaeesti sõna arvatakse olevat laenatud varem, samast allikast või vastavast vanavene sõnast, kusjuures tähendusmuutus 'lokk' > 'helmes' on toimunud eesti keeles (Blokland 2009: 140, Must 2000: 149, Mägiste 1962: 17, 1982-1983: 1015). Vene murretes nimetatakse nõnda ka mitmeid taimi, ent tähenduse 'helmed' kohta andmeid pole (Dal 2: 221, SRNG 16: 9). Samatüveline vene laen esineb sarnases tähenduses ka läänemeresoome idarühma keeltes: isuri ja

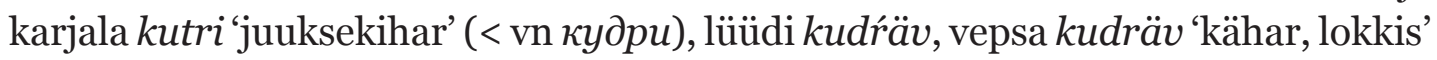
(< vn кудрявый). Ilmselt "Kalevala" kaudu on sõna jõudnud ka soome kirjakeelde: kutrit 'lokid; lokkis juuksed', adj -kutrinen (PS 1: 596, SSA 1: 454).

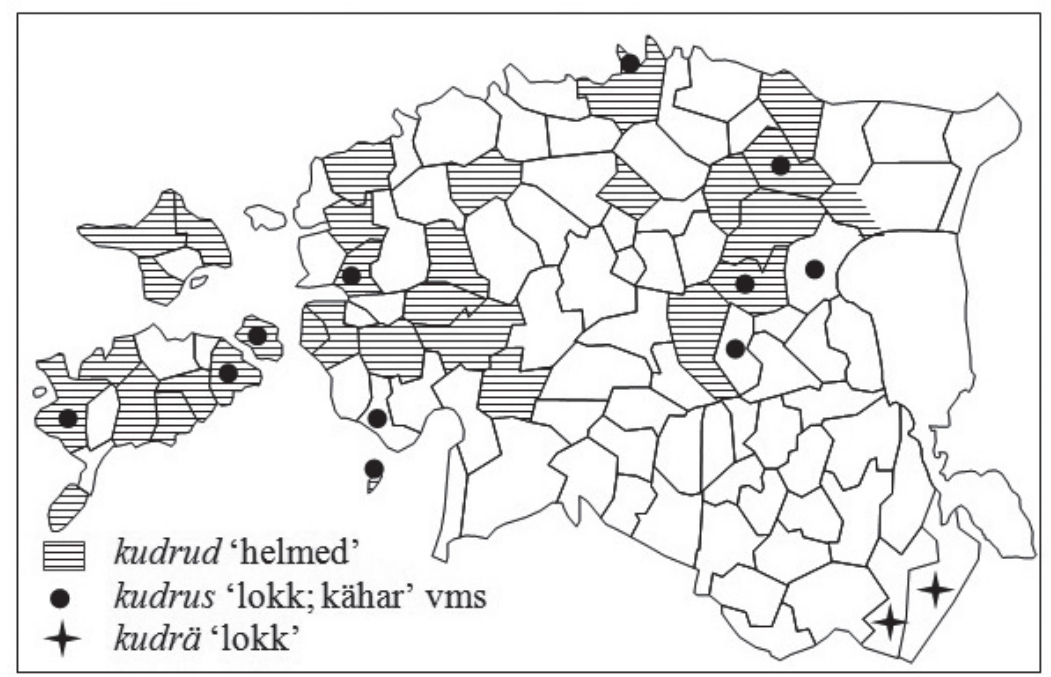

Kaart 2. kudr-tüveliste sõnade tähendused eesti murretes

\section{Kokkuvõtteks}

Eesti keele suurest hulgast laensõnadest on paljud originaaliga häälikuliselt üsna sarnased, kuid tihtilugu ei ole nende tähendus identne ja hästi tuntud tõlkevaste ei pruugi tekstiga sisuliselt sobida. Laenu tähendus võib olla kitsam või laiem kui doonorsõnal või hoopis teisenenud. Laensõnu endid ei saa tähenduserinevuste põhjal alati nii konkreetselt rühmitada, kuna tähendussuhted tervikuna on märksa komplitseeritumad. Sõna, mis on laenatud tähistamaks vaid ühte või osa paljudest doonorkeele tähendustest, on mõnikord eesti keeles kinnistunud veelgi kitsamat mõistet tähistava terminina. Teiselt poolt on algselt ühte mõistet tähistav laensõna originaaltähenduse kõrval omandanud täiesti uusi lisatähendusi. On ka selliseid laensõnu, millel võrreldes originaaliga osa tähendusi puudub, aga samas on uusi juurde tulnud. Ka siis, kui laensõna ja originaali ükski tähendus ei kattu, on tähendusmuutus üldjuhul toimunud mingi seose alusel. Paljude laensõnade sisulist seost laenuallikaga ei ole tänapäeval enam lihtne tajuda, see ilmneb alles taustteabe ja selgituste varal.

Laensõnade tähenduse muutusi on põhjustanud kultuuride erinevus, paikkondlikud etnograafilised iseärasused, eri taime- ja loomaliikide levik, tabu jm. Mitmed sõnad on laenatud tähistamaks üksnes konkreetseid ühiskonnaelu toiminguid ja 
uusi nähtusi või riigikorraldust puudutavate terminitena. Rahvaetümoloogia mõjul võidakse uus laen ühitada varem tuntud, hoopis teist mõistet märkiva sõnaga, andes sellele tähenduse, millel pole laenuallikaga mingit seost. Sageli on sõna tähendus muutunud hiljem, mitte laenamise käigus, kuid alati ei onnestu muutuse aega tuvastada. Hilisemad tähendusmuutused on enamasti tingitud olude või esemete muutumisest.

Laenu päritolu aitab täpsustada võrdlus sarnase sõnaga sugulaskeelte ja kontaktkeelte murretes, pidades seejuures silmas nii levikut kui ka tähenduslikku külge. Samatüveliste sõnade kasutus erinevail Eesti murdealadel erinevas tähenduses osutab, et tegemist võib olla eriaegsete või eri teid pidi saadud laenudega. Laensõna levik murretes aitab sageli määrata laensõna ja ühtlasi kultuuriuuenduse lähtekohta. Sõnatüve häälikulise kuju ja selle arengute kõrval on laenu semantiline külg koos levikupildiga etümologiseerimisel väga tähtis.

\section{Kasutatud lühendid}

adj adjektiiv

asks alamsaksa

gen genitiiv

id. idem 'seesama (tähendus)'

rts rootsi

sks saksa

s.v. $\quad$ sub voce (osutab märksõnale)

van vananenud

vene vene

\section{Viidatud kirjandus}

ALE = Atlas Linguarum Europae (ALE). Volume I, 1-7. Commentaires. Cartes. Assen, Maastricht: Van Gorcum 1983-1990; Roma: Istituto Poligrafico e Zecca dello Stato, 1997-2007.

ALFE = Atlas Linguarum Fennicarum. Itämerensuomalainen kielikartasto. Läänemeresoome keeleatlas. Ostseefinnischer Sprachatlas. Лингвистический атлас прибалтийскофинских языков. ALFE 1-3. Suomalaisen Kirjallisuuden Seuran Toimituksia 80o/1295. Kotimaisten kielten tutkimuskeskuksen julkaisuja 118/159. Helsinki: Suomalaisen Kirjallisuuden Seura, Kotimaisten kielten tutkimuskeskus, 2004-2010.

Ariste, Paul 1942. Etümoloogilisi märkmeid I. - ACUT B XLIX, 1, Tartu, 1-26.

Ariste, Paul 1980. Huvitavat sõnavara rahvakunstiraamatus. - Keel ja Kirjandus XXIII (6), 371-372.

Blokland, Rogier 2009. The Russian Loanwords in Literary Estonian. Veröffentlichungen der Societas Uralo-Altaica 78. Wiesbaden: Harrassowitz.

BVA = Baltu valodu atlants/Baltu kalbų atlasas. Prospekts. Latvijas Universitātes Latviešu valodas institūts, Lietuvių kalbos institutas. Anna Stafecka, Danguolè Mikulènienè (Toim.). Riga, Vilnius: Latvijas Universitātes Latviešu valodas institūts.

Dal = Даль, Владимир 1955. Толковый словарь живаго великорусскаго языка, 2. Москва: Государственное издательство Иностранных и национальных словарей. (Толковый словарь В. Даля ON-LINE: http://vidahl.agava.ru (22.02.2013).)

EKSS = Eesti keele seletav sõnaraamat 1-6. "Eesti kirjakeele seletussõnaraamatu" 2., täiendatud ja parandatud trükk. Margit Langemets, Mai Tiits, Tiia Valdre, Leidi Veskis, Ülle Viks, Piret Voll (Toim.). Eesti Keele Instituut. Tallinn: Eesti Keele Sihtasutus, 2009. 
EMS = Eesti murrete sõnaraamat I-V. Anu Haak, Evi Juhkam, Mari-Liis Kalvik, Mari Kendla, Varje Lonn, Helmi Neetar, Ellen Niit, Piret Norvik, Vilja Oja, Eevi Ross, Aldi Sepp, Tiina Tärk-Laansalu, Jüri Viikberg (Toim.). Eesti Teaduste Akadeemia, Eesti Keele Instituut. Tallinn: Eesti Keele Instituut / Eesti Keele Sihtasutus, 1994-2012.

EMSUKA = Eesti murrete ja soome-ugri keelte arhiiv (Eesti Keele Instituudis, Tallinnas).

ENE = Eesti nõukogude entsüklopeedia, 4. Tallinn: Valgus 1989.

Kallasmaa, Marja 2000. Saaremaa kohanimed II. Tallinn: Eesti Keele Instituut.

Kettunen, Lauri 1938. Livisches Wörterbuch mit grammatischer Einleitung. Lexica Societatis Fenno-Ugricae V. Helsinki: Suomalais-Ugrilainen Seura.

KKS $=$ Karjalan kielen sanakirja, 1. Lexica Societatis Fenno-Ugricae XVI, 1. Kotimaisten kielten tutkimuskeskuksen julkaisuja 25. Helsinki: Suomalais-Ugrilainen Seura, 1968.

LVDA = Latviešu valodas dialektu atlants. Leksika. Latvijas Zinātnu akadēmija. Latviešu valodas institūts. Literatūras, folkloras un mākslas institūts. Rīga: Zinātne, 1999.

Metsmägi, Iris; Sedrik, Meeli; Soosaar, Sven-Erik 2012. Eesti etümoloogiasõnaraamat. Eesti Keele Instituut. Tallinn: Eesti Keele Sihtasutus.

Must, Mari 2000. Vene laensõnad eesti murretes. Tallinn: Eesti Keele Sihtasutus.

Mägiste, Julius 1962. Äldre ryska lånord i estniskan särskilt i det gamla estniska skriftspråket. Lunds Universitets Årsskrift. Ny följd I, 55 (1). Lund: Gleerup.

Mägiste, Julius 1982-1983. Estnisches etymologisches Wörterbuch. Helsinki: FinnischUgrische Gesellschaft.

Nirvi, R. E. 1971. Inkeroismurteiden sanakirja. Lexica Societatis Fenno-Ugricae XVIII. Helsinki: Suomalais-Ugrilainen Seura.

Oja, Vilja 2003. Hobu oli võik, lehm oli leet. - Keel ja Kirjandus XLVI (2), 101-107.

Oja, Vilja 2011. Läänemeresoomlaste keele- ja kultuurikontaktidest laensõnade leviku põhjal. - Eesti Rakenduslingvistika Ühingu aastaraamat, 7, 129-140. http://dx.doi. org/10.5128/ERYa7.08

Plöger, Angela 1973. Die russischen Lehnwörter der finnischen Schriftsprache. Veröffentlichungen der Societas Uralo-altaica 8. Wiesbaden: Otto Harrassowitz.

PS = Suomen kielen perussanakirja. Kotimaisten kielten tutkimuskeskuksen julkaisuja 55 . Helsinki: Edita, Kotimaisten kielten tutkimuskeskus, 1996.

Saareste, Albert 1924. Leksikaalseist vahekordadest eesti murretes I. - ACUD B VI, 1. Tartu.

Saareste, Andrus 1938. Eesti murdeatlas. Atlas des parlers estoniens. I vihik. 28 kaarti. Tartu.

SAOB = Svenska Akademiens ordbok, http://g3.spraakdata.gu.se/saob/ (22.02.2013).

SLW = Winkler, Eberhard; Pajusalu, Karl 2009. Salis-livisches Wörterbuch. Linguistica Uralica. Supplementary Series 3. Tallinn: Teaduste Akadeemia Kirjastus.

SMS = Suomen murteiden sanakirja 7. Kotimaisten kielten tutkimuskeskuksen julkaisuja 36. Helsinki: Suomalaisen Kirjallisuuden Seura, Kotimaisten kielten tutkimuskeskus, 2003.

SRNG 16 = Словарь русских народных говоров. Выпуск 16. Академия наук СССР. Институт русского языка, словарьный сектор. Ленинград: Наука, 1980.

SSA = Suomen sanojen alkuperä. Etymologinen sanakirja. Suomalaisen Kirjallisuuden Seuran toimituksia 556. Kotimaisten kielten tutkimuskeskuksen julkaisuja 62. Helsinki: Suomalaisen Kirjallisuuden Seura, Kotimaisten kielten tutkimuskeskus, 1992-2000.

Suhonen, Seppo 1973. Die jungen lettischen Lehnwörter im Livischen. Suomalais-Ugrilaisen Seuran Toimituksia 154. Helsinki: Suomalais-Ugrilainen Seura.

SVJ = Зайцева, М. И.; Муллонен, М. И. Словарь вепсского языка. Академия наук СССР. Карельский филиал. Институт языка, литературы и истории. Ленинград: Наука, 1972.

Zajceva, Nina 2009. Pari pientä kuvaa aineellisesta ja henkisestä elämästä ALFEn peilaamana ('housut', 'susi'). - Marja Kallasmaa, Vilja Oja (Toim.). Kodukeel ja keele kodu / Home language and the home of a language. Pühendusteos Helmi Neetarile 
75. sünnipäevaks 29. jaanuaril 2009. Eesti Keele Instituudi toimetised 13. Tallinn: Eesti Keele Sihtasutus, 237-249.

Vaba, Lembit 1997. Uurimusi läti-eesti keelesuhetest. Tallinn, Tampere: Eesti Keele Instituut, Tampereen yliopiston suomen kielen ja yleisen kielitieteen laitos.

Vasmer, Max 1920. Indo-germaani laensõnad eesti keeles. - Eesti Kirjandus, 343-346.

Vasmer, Max 1922. Mõned indo-euroopa laensõnad eesti keeles. - Eesti Keel, 11-15.

Vasmer $=$ Фасмер, Макс 1986. Этимологический словарь русского языка. Перевод с немецкого и дополнения члена-корреспондента АН СССР О. Н. Трубачева. Под редакцией и с предисловием проф. Б. А. Ларина. Издание второе, стереотипное. Tом IV. Москва: Прогресс.

VKS = Vadja keele sõnaraamat. Eesti Teaduste Akadeemia, Keele ja Kirjanduse Instituut / Eesti Keele Instituut. Tallinn: Signalet / Eesti Keele Instituut / Eesti Keele Sihtasutus, 1990-2011.

Viires, Ants 1960a. Eesti rahvapärane puutööndus. Ajalooline ülevaade. Tallinn: Eesti Riiklik Kirjastus.

Viires, Ants 196ob. hundilaut ja tengelpung. - Keel ja Kirjandus III (3), 157-158.

Viitso, Tiit-Rein 2006. pagan, põrgu ja papp: kolm kristlikku terminit. - Keel ja Kirjandus, 11, 894-902.

Wharton, Edward Ross 1974. Etymological Lexicon of Classical Greek. Etyma graeca. Chicago: Ares Publishers Inc. Unchanged reprint of the edition: London 1882.

Wiedemann, Ferdinand Johann 1973. Eesti-saksa sõnaraamat. Neljas, muutmata trükk teisest, Jakob Hurda redigeeritud väljaandest [1893]. Tallinn: Valgus.

Vilja Oja (Eesti Keele Instituut) peamised uurimisvaldkonnad on dialektoloogia, geolingvistika, läänemeresoome keeled. Eesti murrete sõnaraamatu koostajaid ja toimetajaid, Läänemeresoome keeleatlase ja Euroopa keelte atlase autoreid.

vilja.oja@eki.ee

Iris Metsmägi (Eesti Keele Instituut) peamised uurimisvaldkonnad on olnud uurali keelte verbimorfoloogia, uurali keelte kontaktid, eesti sõnade päritolu. Eesti etümoloogiasõnaraamatu peatoimetaja.

iris.metsmagi@eki.ee 


\section{SEMANTIC RELATIONS OF LOANWORDS}

\section{Vilja Oja, Iris Metsmägi}

Institute of the Estonian Language

Semantic differences between recent Estonian loanwords and the donor languages are discussed on the background of Estonian dialects and other Finnic languages. The types and reasons for the changes observed, as well as the possible routes of diffusion of the words, are analysed. The data on word origin is based mainly on the Estonian Etymological Dictionary by Metsmägi et al. (2012) if not referred to otherwise.

If the meanings of the borrowing and the source word differ, then the borrowed word may denote (1) a narrower or (2) wider or (3) a totally different concept than the source word. A word borrowed to denote one or part of the source word's meanings may become fixed as a term for a still narrower concept. However, sometimes an originally monosemous loanword may acquire new additional meanings. In other cases, some source meanings are missing, whereas some new ones have been added. Sometimes the source and the loanword share no meanings at all, and the semantic change is detectable only from background information.

The semantic change in loanwords may be caused by cultural differences, local ethnographic specifics, areal distribution of plant and animal species, taboo etc. Folk etymology may change word meaning totally beyond recognition. Often the semantic change takes place later than the time of borrowing. Such later changes are often conditioned by changes of circumstances or objects.

Word origin can be specified by following similar words in the dialects of contact languages, considering their spread and meaning. The variation of word meaning in Estonian dialects may suggest different borrowing times or routes of travel. The areal distribution of loanwords helps to pinpoint the centres of cultural innovations. Thus, an etymologist should consider not only the phonetic shape and developments of a stem, but also its semantic changes, areal distribution of the stem and its meanings in dialects and contact languages.

Keywords: etymology, linguistic contacts, areal distribution of words, semantic change, dialect vocabulary, Estonian, Finnic languages 